УДК 338.439.4:637.5(477)

Іщук Світлана, доктор економічних наук, професор, ДУ «Інститут регіональних досліджень ім. М.І. Долішнього НАН України», завідувач відділу проблем реального сектора економіки регіонів, м. Львів; ORCID ID 0000-0002-3698-9039

https://doi.org/10.29038/2411-4014-2020-01-155-164

e-mail: iso.ird@ukr.net

\title{
СУЧАСНИЙ СТАН І КЛЮЧОВІ ТЕНДЕНЦІЇ ЗАГОТІВЛІ ТА ПРОМИСЛОВОГО ВИРОБНИЦТВА М'ЯСА У РЕГІОНАХ УКРАЇНИ
}

В Україні відбувається системне скорочення сировинної бази для промислової переробки м'яса у зв'язку 3 кризою у тваринництві, передусім у свинарстві і скотарстві. Відтак, у статті досліджено сучасний стан, тенденції та основні напрямки нарощення вітчизняного потенціалу виробництва м'яса. Зокрема, проведено структурно-динамічну оцінку заготівлі та промислового виробництва м’яса в Україні у регіональному розрізі за видами м'ясної сировини і м'ясної продукції, здійснено групування регіонів за масштабами заготівлі та промислової переробки м'яса, проаналізовано зовнішньоекономічні операції у сегменті виробництва м'яса та продуктів із нього, визначено проблеми заготівлі м'ясної сировини в Україні та окреслено перспективи розширення зовнішніх ринків збуту м'яса.

Ключові слова: заготівля м'ясної сировини, виробництво м'яса і м'ясної продукції, курятина, свинина, яловичина, регіони, експорт, імпорт.

Ищук Светлана

доктор экономических наук, профессор,

ГУ «Институт региональных исследований им. М.И. Долишнего НАН Украины», заведующая отделом проблем реального сектора экономики регионов,

г. Львов

\section{ТЕКУЩЕЕЕ СОСТОЯНИЕ И КЛЮЧЕВЫЕ ТЕНДЕНЦИИ ЗАГОТОВКИ И ПРОМЫШЛЕННОГО ПРОИЗВОДСТВА МЯСА В РЕГИОНАХ УКРАИНЫ}

В Украине происходит систематическое сокращение сырьевой базы для промышленной переработки мяса через кризисное состояние животноводства, особенно свиноводства и скотоводства. В статье исследованы текущее состояние, тенденции и основные направления увеличения внутреннего потенциала отечественного мясного производства. В частности, проведена структурно-динамическая оценка заготовки и промышленного производства мяса в Украине в региональном измерении по видам мясного сырья и мясной продукции, осуществлена группировка регионов по масштабам закупок и промышленной переработки мяса, проанализированы внешнеэкономические операции в сегменте производства мяса и продукции, определены проблемы заготовки мясного сырья в Украине и определены перспективы расширения внешних рынков сбыта мяса.

Ключевые слова: заготовка мясного сырья, производство мяса и мясной продукции, куриное мясо, свинина, говядина, регионы, экспорт, импорт.

Ishchuk Svitlana

Dr. Sc. (Econ.), Professor, SI «Institute of Regional Research n.a. M.I. Dolishniy of the NAS of Ukraine», Head of the Department of problems of real sector of regions economy,

Lviv

\section{CURRENT SITUATION AND KEY TRENDS OF MEAT PROCUREMENT AND INDUSTRIAL PRODUCTION IN REGIONS OF UKRAINE}


Production of meat and meat products is one of the key segments of domestic processing industry. In 2018, its share in total food production in Ukraine reached $17.78 \%$ (vs. 15.93\% in 2013). At the same time, the main problem holding back the development of this segment is the reduction of the raw material base for the industrial processing of meat due to the crisis in animal husbandry, especially in pig and cattle breeding. The purpose of the article is to define the current state, trends and prospects of increasing the capacity of meat production in the regions of Ukraine. According to the results of research, during 2014-2018 the total volume of meat procurement by livestock farms in Ukraine decreased by $1.41 \%$. The cuts in procurement were characteristic for all types of meat except poultry. Accordingly, chicken dominates the structure of procured meat (with a share of $53.46 \%$ in 2018) and in the structure of industrial meat production (57.36\%). Despite the reduction of the raw material base, there is a gradual increase in meat production in Ukraine. Thus, in 2018, $87.81 \%$ of raw materials procured by agricultural producers were sent for processing (vs. $82.11 \%$ in 2013). However, only the five regions specialize in meat products, meaning that in their meat production structures the advanced meat processing is dominated. Based on the differentiation of the regions of Ukraine by the scale of raw material procurement and meat production, it is determined that the vast majority (15) of regions do not have significant potential in this segment of the economy. The meat procurement and meat industrial production are highly concentrated in the territories - in $2018,54.67 \%$ of meat and $64.51 \%$ of meat products were produced in five regions (Vinnytsia, Dnipro, Kyiv, Lviv and Cherkasy). Despite the negative trends in the production of meat and meat products in general, there has been a positive foreign trade balance of these goods since 2014 in Ukraine. The current global economic environment offers significant opportunities for increasing Ukrainian exports of chicken and other niche poultry meat. With the increase in livestock, the prospects for increasing external supplies of pork and beef are promising.

Keywords: raw meat procurement, production of meat and meat products, chicken, pork, beef, regions, exports, imports.

Постановка проблеми та ії значення. Виробництво м'яса та м'ясних продуктів - один із ключових сегментів вітчизняної харчової промисловості. У 2018 році його частка у загальному виробництві харчових продуктів в Україні досягла 17,78\% (проти 15,93\% у 2013-му). Водночас основною проблемою, яка стримує розвиток названого сегмента, є скорочення сировинної бази для промислової переробки м'яса через кризовий стан тваринництва. Своєю чергою, негативні зміни у заготівлі основних видів тваринницької продукції стали наслідком несистемної та неефективної трансформації українського агропрому шляхом руйнування великих спеціалізованих господарств із вирощування та відгодівлі, передусім, великої рогатої худоби і свиней. У підсумку, до 2013 року (порівняно з 1990-м) виробництво продукції тваринництва в усіх категоріях сільськогосподарських підприємств в Україні скоротилось на понад 50\%. У подальшому падіння значень цього показника призупинилось, але внаслідок зростання лише одного сегмента - птахівництва (заготівлі м'яса курятини). Натомість вітчизняне свинарство і скотарство продовжує перебувати у кризовому стані, передусім через скорочення поголів'я свиней і великої рогатої худоби (BPX).

Аналіз останніх досліджень і публікацій. 3 огляду на стратегічну важливість агропромислової сфери для забезпечення соціально-економічного розвитку, вітчизняними науковцями проведено ряд комплексних досліджень аграрного ринку, зокрема, інституційного середовища продовольчого ринку в Україні з урахуванням світового досвіду [1; 2]. У [3] широко висвітлено науково-аналітичні засади формування організаційно-економічного механізму збалансованого розвитку ринку м'яса та м'ясопродуктів, а сучасні тенденції функціонування сектора м'ясопереробки в Україні досліджено в [4].

Мета і завдання статті. Метою дослідження $є$ визначення сучасного стану, тенденцій та перспектив нарощення потенціалу виробництва м'яса у регіонах України. Для досягнення поставленої мети було вирішено низку завдань: проведено структурно-динамічну оцінку заготівлі та промислового виробництва м'яса в Україні у регіональному розрізі за видами м'ясної сировини і м’ясної продукції; здійснено групування регіонів за масштабами заготівлі та промислової переробки м’яса; проведено аналіз зовнішньоекономічних операцій у сегменті виробництва м'яса та продуктів iз нього; визначено проблеми заготівлі м’ясної сировини в Україні та окреслено перспективи розширення зовнішніх ринків збуту м'яса.

Викладення основного матеріалу та обгрунтування отриманих результатів дослідження. Упродовж 2014-2018 років загальний обсяг заготівлі м'яса тваринницькими господарствами зменшився на 1,41\% (табл. 1). Проте, у 2018 році відбулось зростання значень цього показника, яке 
було досягнуто у 13-ти регіонах, а найбільше - у Миколаївській (на 15,38\%) і Вінницькій (на 9,85\%) областях.

Темпи приросту заготівлі м'яса в Украӥні (у забійній масі), \%

\begin{tabular}{|l|c|c|c|c|c|c|}
\hline \multicolumn{1}{|c|}{ Показник } & $\mathbf{2 0 1 4 / 2 0 1 3}$ & $\mathbf{2 0 1 5 / 2 0 1 4}$ & $\mathbf{2 0 1 6 / 2 0 1 5}$ & $\mathbf{2 0 1 7 / 2 0 1 6}$ & $\mathbf{2 0 1 8 / 2 0 1 7}$ & $\mathbf{2 0 1 8 / 2 0 1 3}$ \\
\hline М'ясо птиці & $-0,31$ & $-1,80$ & 2,02 & 1,53 & 6,26 & 7,75 \\
\hline Свинина & $-0,76$ & 2,30 & $-1,59$ & $-1,57$ & $-4,53$ & $-6,11$ \\
\hline $\begin{array}{l}\text { Яловичина i } \\
\text { телятина }\end{array}$ & $-3,53$ & $-6,95$ & $-2,19$ & $-3,22$ & $-1,27$ & $-16,11$ \\
\hline Інші види м'яса & $-12,24$ & $-9,04$ & $-4,55$ & 1,49 & 1,17 & $-21,77$ \\
\hline Всього & $\mathbf{- 1 , 2 5}$ & $\mathbf{- 1 , 5 3}$ & $\mathbf{0 , 0 4}$ & $\mathbf{- 0 , 2 3}$ & $\mathbf{1 , 5 8}$ & $\mathbf{- 1 , 4 1}$ \\
\hline
\end{tabular}

Джерело: авторські розрахунки за даними Державної служби статистики України [5]

В Україні спостерігається стала тенденція до зростання заготівлі м’яса птииі. Упродовж аналізованого періоду потенціал розвитку птахівництва найбільше наростили Вінницька $(+133,56 \%)$, Житомирська $(+92,45 \%)$ і Сумська $(+55,56 \%)$ області. У 2018 році додатних темпів приросту заготівлі м'яса птиці було досягнуто у 16-ти регіонах, зокрема, найвищих - у Херсонській (54,55\%) та Івано-Франківській $(47,55 \%)$ областях. Також із 2017 року в Україні зростали обсяги заготівлі інших видів м'яса (конини, кролятини, баранини та козлятини). У 2018 році приріст цих видів м'яса забезпечили шість областей: Вінницька $(+23,53 \%)$, Житомирська $(+13,89 \%)$, Закарпатська $(+17,65 \%)$, Запорізька $(+15,38 \%)$, Київська $(+5,56 \%)$ і Львівська $(+5,0 \%)$.

Водночас відбувається зменшення заготівлі свинини - у 2018 році лише в 7-ми регіонах зросло значення цього показника. Із них Сумська і Тернопільська області є лідерами за нарощенням потенціалу свинарства за останні 5 років: $+53,33 \%$ і $+41,53 \%$ відповідно. Подібна ситуація і 3 заготівлею яловичини та телятини - у 2018 році зростання було досягнуто лише в 6-ти регіонах, iз них найбільше у Миколаївській - 39,69\% (+57,76\%, порівняно з 2013-м).

Наслідком описаної динаміки стали зміни у структурі заготовленого м'яса. Так, упродовж 20142018 років частка м'яса птиці у цій структурі збільшилась на 4,55 в.п., але, натомість, частка свинини зменшилась на 1,49 в.П., яловичини і телятини - на 2,67 в.П., інших видів м'яса - на 0,39 в.п. (табл. 2). У 2018 році 74,10\% заготовленого в Україні м'яса птиці припадало на чотири області: Вінницьку (24,55\% проти $12,07 \%$ у 2013-му), Черкаську (22,11\% проти 23,95\%), Дніпропетровську (16,17\% проти $15,06 \%)$ і Київську (11,27\% проти 14,93\%). Загалом на заготівлі м’яса птиці спеціалізуються тваринницькі господарства 8-ми регіонів, до яких, окрім названих, входять ще Волинська, Львівська, Рівненська і Харківська області.

Структура заготовленого в Украӥні м'яса (за видами у забійній масі), \%

\begin{tabular}{|l|r|r|r|r|r|r|}
\hline \multicolumn{1}{|c|}{ Показник } & $\mathbf{2 0 1 3}$ & $\mathbf{2 0 1 4}$ & $\mathbf{2 0 1 5}$ & $\mathbf{2 0 1 6}$ & $\mathbf{2 0 1 7}$ & $\mathbf{2 0 1 8}$ \\
\hline М'ясо птиці & 48,91 & 49,38 & 49,24 & 50,22 & 51,10 & 53,46 \\
\hline Свинина & 31,33 & 31,48 & 32,71 & 32,17 & 31,74 & 29,84 \\
\hline Яловичина і телятина & 17,91 & 17,50 & 16,53 & 16,16 & 15,68 & 15,24 \\
\hline Інші види м'яса & 1,85 & 1,64 & 1,52 & 1,45 & 1,47 & 1,46 \\
\hline Всього & $\mathbf{1 0 0 , 0 0}$ & $\mathbf{1 0 0 , 0 0}$ & $\mathbf{1 0 0 , 0 0}$ & $\mathbf{1 0 0 , 0 0}$ & $\mathbf{1 0 0 , 0 0}$ & $\mathbf{1 0 0 , 0 0}$ \\
\hline
\end{tabular}

Джерело: авторські розрахунки за даними Державної служби статистики України [5]

На відміну від висококонцентрованої (територіально) заготівлі м’яса птиці, заготівля свинини, яловичини і телятини, а також інших видів м'яса в Україні є більш диверсифікованою. Так, на чотири області (Київську, Донецьку, Львівську і Полтавську), які є лідерами із заготівлі свинини, у 2018 році сумарно припадало 31,63\% обсягу цього виду м'яса. Заготівля свинини є профільною спеціалізацією тваринницьких господарств у 14-ти регіонах. Ще більш диверсифікованою у 
регіональному розрізі є заготівля яловичини і телятини - у 2018 році $27,95 \%$ обсягу цього виду м'яса припало на чотири області-лідери у цьому сегменті: Івано-Франківську, Львівську, Харківську і Хмельницьку. На заготівлі яловичини і телятини традиційно спеціалізується Миколаївська область, а 32015 року - і Луганська (внаслідок втрати виробничих потужностей птахофабрик). Близько 50\% заготівлі конини, кролятини, баранини та козлятини сконцентровано у 6-ти областях: Вінницькій $(6,09 \%)$, Житомирській $(11,88 \%)$, Закарпатській $(11,59 \%)$, Київській $(5,51 \%)$, Львівській $(6,09 \%)$ і Одеській $(8,12 \%)$. На заготівлі цих видів м'яса не спеціалізуються тваринницькі господарства жодного регіону.

Попри скорочення сировинної бази, в Україні відбувається поступове нарощення промислового виробництва м'яса. Так, у 2018 році 87,81\% м'ясної сировини, заготовленої сільськогосподарськими товаровиробниками, було спрямовано на промислову переробку, що на 5,7 в.п. більше, аніж у 2013му. У двох областях - Дніпропетровській і Полтавській - обсяги промислового виробництва м'яса перевищують обсяги його заготівлі (у забійній масі) на 25,22\% і 5,39\% відповідно (табл. 3). Дуже високий потенціал розвитку м'ясопереробних виробництв демонструють також Донецька і Львівська області. У цих регіонах частка промислового виробництва м'яса і м'ясопродуктів у заготівлі м'ясної сировини (у забійній масі) становила 96,49\% (проти $89,35 \%$ у 2013 році) і 83,25\% (проти 46,83\%) відповідно.

Співвідношення між обсягами промислового виробництва і заготівлі м'яса, \%

\begin{tabular}{|c|c|c|c|c|c|c|}
\hline Область & 2013 & 2014 & 2015 & 2016 & 2017 & 2018 \\
\hline Вінницька & 26,11 & 16,81 & 14,57 & 9,93 & 61,50 & 17,66 \\
\hline Волинська & 54,72 & 51,92 & 41,83 & 4,82 & 10,09 & 12,31 \\
\hline Дніпропетровська & 111,35 & 114,78 & 128,94 & 122,70 & 122,96 & 125,22 \\
\hline Донецька & 89,35 & 85,47 & 79,58 & 97,14 & 97,76 & 96,49 \\
\hline Житомирська & 35,28 & 48,24 & 51,87 & 50,02 & 47,17 & 36,36 \\
\hline Закарпатська & 4,40 & 4,02 & 4,79 & 5,33 & 5,99 & 5,83 \\
\hline Запорізька & 51,44 & 54,43 & 51,11 & 51,55 & 58,25 & 53,17 \\
\hline Івано-Франківська & 31,11 & 26,87 & 26,72 & 22,13 & 17,64 & 19,68 \\
\hline Київська & 61,60 & 67,94 & 69,78 & 63,68 & 59,20 & 64,04 \\
\hline Кіровоградська & 61,43 & 59,81 & 53,94 & 48,66 & 43,01 & 41,04 \\
\hline Луганська & 98,00 & 78,93 & 3,70 & 3,30 & 5,36 & 4,60 \\
\hline Львівська & 46,83 & 50,25 & 62,70 & 71,40 & 81,39 & 83,25 \\
\hline Миколаївська & 7,38 & 5,54 & 6,77 & 5,03 & 3,92 & 4,30 \\
\hline Одеська & 24,45 & 22,27 & 17,22 & 15,52 & 14,67 & 14,86 \\
\hline Полтавська & 105,32 & 117,03 & 58,16 & 112,34 & 113,84 & 105,39 \\
\hline Рівненська & 8,15 & 7,82 & 12,54 & 17,73 & 17,95 & 17,90 \\
\hline Сумська & 20,14 & 17,33 & 15,30 & 12,20 & 12,71 & 12,43 \\
\hline Тернопільська & 24,55 & 16,60 & 15,91 & 21,80 & 30,93 & 37,78 \\
\hline Харківська & 31,41 & 33,90 & 30,71 & 29,73 & 40,16 & 68,69 \\
\hline Херсонська & 4,52 & 4,55 & 7,40 & 5,82 & 6,83 & 4,65 \\
\hline Хмельницька & 32,44 & 27,99 & 20,97 & 21,27 & 21,11 & 19,06 \\
\hline Черкаська & 43,30 & 32,90 & 30,68 & 33,71 & 33,54 & 20,73 \\
\hline Чернівецька & 24,93 & 22,00 & 19,65 & 14,56 & 15,15 & 10,12 \\
\hline Чернігівська & 24,79 & 18,51 & 24,01 & 21,11 & 23,18 & 23,82 \\
\hline
\end{tabular}

Джерело: авторські розрахунки за даними Державної служби статистики України [5; 6]

Згідно з попередніми даними ДССУ, у 2019 році, після 3-річної позитивної динаміки, темп приросту промислового виробництва м'яса та м'ясних продуктів в Україні знову став від'ємним (табл. 4). Найбільше падіння виробництва відбулось у сегментах іншого м'яса (конини, кролятини, баранини та козлятини) і субпродуктів, а також яловичини і телятини (негативний тренд із 2017 року).

Упродовж аналізованого періоду нарощення потенціалу промислового виробництва м'яса та м'ясних продуктів досягли третина областей, зокрема: Рівненська $(+115,24 \%)$, Харківська $(+97,73 \%)$, Тернопільська $(+82,68 \%)$, Львівська $(+75,37 \%)$, Вінницька $(+33,76 \%)$, Закарпатська $(+27,94 \%)$, Дніпропетровська $(+22,0 \%)$ і Житомирська $(+4,01 \%)$. Однак, у 2018 році позитивну динаміку 
виробництва у цьому сегменті харчової промисловості продемонстрували лише чотири перші області з наведеного переліку, а також Волинська, Київська і Миколаївська.

Темпи приросту промислового виробництва м'яса

Таблиия 4

та м'ясних продуктів в Україні, \%

\begin{tabular}{|c|l|c|c|c|c|c|c|}
\hline $\begin{array}{c}\text { Код } \\
\text { продy } \\
\text { к-ціï }\end{array}$ & Назва продукцї & $\begin{array}{c}\mathbf{2 0 1 4 /} \\
\mathbf{2 0 1 3}\end{array}$ & $\begin{array}{c}\mathbf{2 0 1 5 /} \\
\mathbf{2 0 1 4}\end{array}$ & $\begin{array}{c}\mathbf{2 0 1 6 /} \\
\mathbf{2 0 1 5}\end{array}$ & $\begin{array}{c}\mathbf{2 0 1 7 /} \\
\mathbf{2 0 1 6}\end{array}$ & $\begin{array}{c}\mathbf{2 0 1 8 /} \\
\mathbf{2 0 1 7}\end{array}$ & $\begin{array}{c}\mathbf{2 0 1 9 /} \\
\mathbf{2 0 1 8}\end{array}$ \\
\hline \multirow{2}{*}{10.11} & $\begin{array}{l}\text { М'ясо (охолоджене і } \\
\text { заморожене), в т.ч.: }\end{array}$ & 6,46 & $-0,05$ & 4,24 & $-2,04$ & 1,08 & $-10,95$ \\
\cline { 2 - 8 } & $\begin{array}{l}\text { яловичина і } \\
\text { телятина }\end{array}$ & $-10,93$ & $-0,12$ & 7,89 & $-3,51$ & $-1,47$ & $-19,97$ \\
\cline { 2 - 8 } & свинина & 16,59 & $-0,45$ & 2,99 & $-1,47$ & 2,23 & $-5,82$ \\
\cline { 2 - 8 } & $\begin{array}{l}\text { інше м'ясо та } \\
\text { субпродукти }\end{array}$ & 4,60 & 31,23 & $-16,53$ & 5,83 & 2,36 & $-84,86$ \\
\hline \multirow{2}{*}{10.12} & $\begin{array}{l}\text { М'ясо свійської } \\
\text { птиці }\end{array}$ & $-3,12$ & 1,69 & 5,37 & 5,41 & 7,77 & $-2,10$ \\
\hline 10.13 & М'ясні продукти & $-11,68$ & $-8,02$ & $-3,62$ & 1,00 & 2,22 & $-3,38$ \\
\hline \multicolumn{2}{|c|}{ Всього } & $\mathbf{- 3 , 6 7}$ & $\mathbf{- 1 , 2 4}$ & $\mathbf{2 , 9 2}$ & $\mathbf{2 , 7 2}$ & $\mathbf{5 , 0 8}$ & $\mathbf{- 4 , 2 1}$ \\
\hline
\end{tabular}

Джерело: авторські розрахунки за даними Державної служби статистики України [6]

Промислове виробництво м'яса та м'ясних продуктів в Україні, як і заготівля м'ясної сировини, є територіально висококонцентрованим. Так, у 2018 році 52,4\% (проти 39,80\% у 2013-му) обсягу цього виробництва було зосереджено у 3-х областях: Дніпропетровській, Київській і Львівській. Порівняно значними (>5\%) у цій структурі є також частки Вінницької, Донецької, Полтавської, Харківської і Черкаської областей. Водночас частка решти 16-ти регіонів сумарно становила лише $16,0 \%$.

У структурі промислового виробництва м'яса та м'ясних продуктів в Україні домінує м'ясо свійської птиці, частка якого за останні 6 років зросла на 7,22 в.п. (табл. 5). Натомість частка м'ясних продуктів (які включають ковбасні, копчені, консервовані та інші вироби із м'яса) скоротилась на 6,54 в.п. Такі тенденції свідчать про згортання поглибленої переробки м'ясної сировини, зокрема, свинини, яловичини і телятини та ін. видів. Значною мірою це спричинено низьким рівнем операційної рентабельності виробництва м'ясних продуктів в Україні - 2,6\% у 2018 році проти $(3,7 \%$ у 2013-му), тоді як рентабельність виробництва м'яса свійської птиці досягла 11,3\% (проти 9,1\%).

Структура промислового виробництва м'яса

Таблиия 5 та м'ясних продуктів в Україні, \%

\begin{tabular}{|c|l|c|c|c|c|c|c|c|}
\hline $\begin{array}{c}\text { Код } \\
\text { продук- } \\
\text { ції }\end{array}$ & \multicolumn{1}{|c|}{ Назва продукцї } & $\mathbf{2 0 1 3}$ & $\mathbf{2 0 1 4}$ & $\mathbf{2 0 1 5}$ & $\mathbf{2 0 1 6}$ & $\mathbf{2 0 1 7}$ & $\mathbf{2 0 1 8}$ & $\mathbf{2 0 1 9}$ \\
\hline 10.11 & $\begin{array}{l}\text { М'ясо (охолоджене і } \\
\text { заморожене), в т.ч.: }\end{array}$ & 19,93 & 22,02 & 22,29 & 22,58 & 21,53 & 20,71 & 19,25 \\
\hline & яловичина і телятина & 7,25 & 6,71 & 6,78 & 7,11 & 6,68 & 6,26 & 5,23 \\
\hline & свинина & 12,49 & 15,11 & 15,23 & 15,24 & 14,62 & 14,23 & 13,99 \\
\hline & $\begin{array}{l}\text { інше м'ясо та } \\
\text { субпродукти }\end{array}$ & 0,19 & 0,20 & 0,27 & 0,22 & 0,23 & 0,22 & 0,04 \\
\hline 10.12 & $\begin{array}{l}\text { М'ясо свійської } \\
\text { птиці }\end{array}$ & 51,40 & 51,69 & 53,23 & 54,49 & 55,92 & 57,36 & 58,62 \\
\hline 10.13 & М'ясні продукти & 28,67 & 26,29 & 24,49 & 22,93 & 22,55 & 21,93 & 22,13 \\
\hline & Всього & $\mathbf{1 0 0 , 0}$ & $\mathbf{1 0 0 , 0}$ & $\mathbf{1 0 0 , 0}$ & $\mathbf{1 0 0 , 0}$ & $\mathbf{1 0 0 , 0}$ & $\mathbf{1 0 0 , 0}$ & $\mathbf{1 0 0 , 0}$ \\
\hline
\end{tabular}

Джерело: авторські розрахунки за даними Державної служби статистики України [6] 
Негативна динаміка наведених структурних показників пов'язана зі скороченням поглибленої переробки м'яса. Так, упродовж 2014-2019 років частка м'ясних продуктів у структурі промислового виробництва м'яса в Україні зменшилась на 22,78\% - від 286,6 кг/т у 2013 році до 221,3 кг/т у 2019му. Серед регіонів лідерами за значенням цього показника є Одеська, Кіровоградська і Житомирська області, в яких частка м'ясних продуктів у структурі промислового виробництва м'яса стабільно перевищує $60 \%$.

На виробництві м'ясних продуктів спеціалізується сектор м'ясопереробки харчової промисловості 10-ти регіонів, до яких (окрім названих вище) входять: Волинська, Донецька, Закарпатська, Запорізька, Миколаївська, Полтавська і Харківська області. За останні 5 років лише шість регіонів сумарно збільшили обсяги виробництва м'ясних продуктів, тобто наростили свій потенціал поглибленої промислової переробки м'яса. Це передусім області, які спеціалізуються на виробництві м'ясних продуктів - Житомирська $(+25,95 \%)$, Закарпатська $(+194,67 \%)$, Запорізька $(+25,95 \%)$ і Харківська $(+27,61 \%)$, а також Вінницька $(+246,95 \%)$ і Дніпропетровська $(+37,51 \%)$. Понад $50 \%$ виробництва м'ясних продуктів в Україні сконцентровано у 3-х областях: Дніпропетровській (27,39\%), Донецькій $(12,0 \%)$ і Полтавській (11.67\%), тобто у тих регіонах, де найвище значення показника співвідношення між обсягами промислового виробництва м’яса і обсягами його заготівлі.

Групування регіонів України за обсягами заготівлі (у забійній масі)

Таблиия 6 і промислового виробництва м'яса

\begin{tabular}{|c|c|c|c|}
\hline № zpynu & Характеристика групи & 2013 & 2018 \\
\hline $\mathrm{I}$ & $\begin{array}{l}\text { Значні обсяги заготівлі } \\
\text { і промислового виробництва м'яса }\end{array}$ & $\begin{array}{l}\text { Волинська } \\
\text { Дніпропетровська } \\
\text { Донецька* } \\
\text { Київська } \\
\text { Львівська } \\
\text { Черкаська }\end{array}$ & $\begin{array}{l}\text { Вінницька } \\
\text { Дніпропетровська } \\
\text { Київська } \\
\text { Львівська } \\
\text { Черкаська }\end{array}$ \\
\hline II & $\begin{array}{l}\text { Значні обсяги промислового } \\
\text { виробництва м'яса при невеликих } \\
\text { обсягах його заготівлі }\end{array}$ & $\begin{array}{l}\text { Луганська } \\
\text { Полтавська* }\end{array}$ & $\begin{array}{l}\text { Донецька* } \\
\text { Полтавська* } \\
\text { Харківська* } \\
\end{array}$ \\
\hline III & $\begin{array}{l}\text { Невеликі обсяги промислового } \\
\text { виробництва м’яса при значних } \\
\text { обсягах його заготівлі }\end{array}$ & Вінницька & Волинська* \\
\hline IV & $\begin{array}{l}\text { Невеликі обсяги заготівлі } \\
\text { і промислового виробництва м'яса }\end{array}$ & $\begin{array}{l}\text { Житомирська* } \\
\text { Закарпатська } \\
\text { Запорізька } \\
\text { Івано-Франківська } \\
\text { Кіровоградська* } \\
\text { Миколаївська* } \\
\text { Одеська* } \\
\text { Рівненська } \\
\text { Сумська } \\
\text { Тернопільська } \\
\text { Харківська* } \\
\text { Херсонська } \\
\text { Хмельницька } \\
\text { Чернівецька } \\
\text { Чернігівська }\end{array}$ & $\begin{array}{l}\text { Житомирська* } \\
\text { Закарпатська* } \\
\text { Запорізька* } \\
\text { Івано-Франківська } \\
\text { Кіровоградська* } \\
\text { Луганська } \\
\text { Миколаївська* } \\
\text { Одеська* } \\
\text { Рівненська } \\
\text { Сумська } \\
\text { Тернопільська } \\
\text { Херсонська } \\
\text { Хмельницька } \\
\text { Чернівецька } \\
\text { Чернігівська }\end{array}$ \\
\hline
\end{tabular}

* Спеціалізація регіону на виробництві м'ясних продуктів

Джерело: авторська розробка

Результати проведених оцінок дали підстави для диференціації регіонів України на чотири групи за масштабами заготівлі м'ясної сировини та промислового виробництва м'яса і м'ясопродуктів. Як видно $з$ табл. 6, переважна більшість (15) областей належать до 4-ї групи, тобто не володіють значним потенціалом ані заготівлі, ані промислового виробництва м'яса. Водночас у межах перших трьох груп упродовж 2014-2018 років відбулись певні зміни. Так, дві області - Вінницька і Харківська - піднялись, 
відповідно, у 1-шу і 2-гу групи завдяки нарощенню обсягів промислової переробки м’яса. Але натомість три області перемістились у нижчі групи. Зокрема, Волинська - у 3-тю (внаслідок скорочення промислового виробництва м'яса), а Донецька - у 2-гу (внаслідок зменшення заготівлі м'яса). Луганська область практично втратила свій виробничий потенціал у сегменті промислової переробки м'яса, тоді як обсяги заготівлі м'ясної сировини скоротились до мінімуму - 0,3\% у регіональній структурі (проти $2,2 \%$ у 2013 році).

Виробництво м’яса $є$ експортоорієнтованим сегментом вітчизняної харчової промисловості. Так, у 2018 році частка експорту у промисловому випуску м'яса склала 23,42\%, що на 10,86 в.п. більше, аніж у 2013-му. Водночас частка експорту у випуску м'ясних продуктів становила лише 0,68\% (проти $0,53 \%$ ). Тобто на зовнішніх ринках реалізується лише продукція первинної переробки м'яса. У структурі українського експорту м'яса та продуктів із нього стабільно домінують товари групи «М'ясо та їстівні субпродукти» (20 код за Українською класифікацією товарів зовнішньоекономічної діяльності (УКТЗЕД)). У 2018 році їх частка становила 99,19\% (98,34\% у 2013-му), зокрема, на товари підгрупи «М'ясо та їстівні субпродукти птиці» (207 код) припало 86,09\% (81,44\%). За 11 місяців 2019 року значення цих показників досягли 99,36\% і 88,91\% відповідно.

Таблиия 7

Коефіцієнт покриття імпорту експортом

\begin{tabular}{|c|c|c|c|c|c|c|c|c|}
\hline $\begin{array}{l}\text { Код } \\
\text { за } \\
\text { УКТ } \\
\text { ЗЕД }\end{array}$ & Назва продукцї & 2013 & 2014 & 2015 & 2016 & 2017 & 2018 & $\begin{array}{l}11 \\
\text { місяців } \\
2019\end{array}$ \\
\hline 20 & $\begin{array}{l}\text { М'ясо та їстівні } \\
\text { субпродукти }\end{array}$ & $\mathbf{0 , 5 5}$ & 1,59 & 3,74 & 4,70 & 4,70 & $\mathbf{3 , 8 8}$ & 4,48 \\
\hline 201 & $\begin{array}{l}\text { М'ясо великої рогатої } \\
\text { худоби, свіже або } \\
\text { охолоджене }\end{array}$ & 38,11 & 18,67 & 26,53 & 40,15 & 26,52 & 28,10 & 26,74 \\
\hline 202 & $\begin{array}{l}\text { М'ясо великої рогатої } \\
\text { худоби, морожене }\end{array}$ & 3,37 & 8,00 & 23,07 & 13,85 & 29,67 & 19,53 & 23,13 \\
\hline 203 & Свинина & 0,05 & 0,33 & 6,71 & 1,22 & 1,06 & 0,07 & 0,11 \\
\hline 204 & Баранина, козлятина & 0,02 & 1,81 & 0,25 & 0,40 & 2,15 & 2,00 & 4,47 \\
\hline 206 & $\begin{array}{l}\text { Субпродукти великої } \\
\text { рогатої худоби, } \\
\text { свиней, овець, коней }\end{array}$ & 0,03 & 0,13 & 0,18 & 0,46 & 0,78 & 0,41 & 0,25 \\
\hline 207 & $\begin{array}{l}\text { М'ясо та їстівні } \\
\text { субпродукти птиці }\end{array}$ & 2,29 & 4,79 & 6,06 & 8,53 & 8,03 & 9,76 & 11,03 \\
\hline 208 & $\begin{array}{l}\text { Інші м'ясо та їстівні } \\
\text { субпродукти }\end{array}$ & 0,00 & 0,02 & 3,00 & 0,03 & 0,01 & 0,07 & 0,45 \\
\hline 209 & $\begin{array}{l}\text { Сало, свинячий жир і } \\
\text { жир птиці }\end{array}$ & 0,00 & 0,00 & 0,24 & 0,00 & 0,00 & 0,00 & 0,00 \\
\hline 210 & $\begin{array}{l}\text { М'ясо та м'ясні } \\
\text { субпродукти }\end{array}$ & 0,40 & 0,72 & 0,11 & 0,18 & 0,74 & 1,22 & 0,61 \\
\hline 16 & Продукти з м'яса & 2,30 & 1,83 & 1,34 & 1,22 & 1,98 & 1,82 & 2,72 \\
\hline 1601 & $\begin{array}{l}\text { Ковбаси та аналогічні } \\
\text { вироби з м'яса }\end{array}$ & 1,03 & 1,25 & 1,79 & 4,33 & 3,00 & 3,33 & 5,91 \\
\hline 1602 & $\begin{array}{l}\text { Інші готові чи } \\
\text { консервовані } \\
\text { м’ясопродукти } \\
\end{array}$ & 3,21 & 2,12 & 1,26 & 1,03 & 1,81 & 1,57 & 2,13 \\
\hline & $\begin{array}{c}\text { Всього } \\
(\text { код 20 + код 16) }\end{array}$ & $\mathbf{0 , 5 5}$ & 1,51 & 3,46 & 4,22 & 4,19 & 3,56 & 3,91 \\
\hline
\end{tabular}

Джерело: авторські розрахунки за даними Державної служби статистики України [7]

Упродовж 2014-2018 років сумарні темпи приросту українського експорту м'яса та продуктів із нього склали 113,89\%. Зокрема, обсяги експорту м'яса та їстівних субпродуктів зросли на $115,74 \%$, 
тоді як продуктів із м'яса (код 16) - лише на 4,3\%. Водночас сумарний імпорт м'яса за вказаний період скоротився на $19,13 \%$, а надто продуктів із м'яса - на 61,29\%. Товарна структура українського імпорту в досліджуваному сегменті харчової промисловості аналогічна структурі експорту - у ній домінують м'ясо та їстівні субпродукти птиці (55,78\% у 2019 році). Проте, Україна імпортувала дешевші види м'ясної продукції: середньорічна ціна експорту м'яса та їстівних субпродуктів птиці у 2018 році становила $\$ 1,54 /$ кг, а імпорту - $\$ 0,38 /$ кг; експорту свинини - $\$ 2,15 /$ кг, а імпорту - $\$ 1,82 /$ кг.

Із 2014 року в Україні позитивне сальдо зовнішньої торгівлі товарами у сегменті м'яса та продуктів із нього. Так, за 11 місяців 2019 року коефіцієнт покриття імпорту експортом склав 3,91 проти 0,55 у 2013-му (табл. 7). Найвище значення цього показника характерне для м'яса великої рогатої худоби (коди 201, 202) і птиці (код 207). Натомість імпорт свинини (коди 206, 208-210) із 2018 року після 3-річної перерви знову домінує над експортом, що є прямим наслідком зменшення поголів'я свиней, спричиненого Африканською чумою свиней (АЧС).

У регіональному розрізі найбільшими імпортерами м'яса та їстівних субпродуктів є Львівська, Волинська і Дніпропетровська області, на які у 2019 році сумарно припадало 60,03\% увезеного м'яса (проти 77,24\% у 2018-му). Водночас ключовим експортером м'яса та їстівних субпродуктів 3 України є Київська область - 26,05\% за 11 місяців 2019 року (проти 33,47\%). У вітчизняному роздрібному товарообороті частка імпорту у сегменті м'яса та продуктів із нього становить понад $25 \%$ [8]. Найвище значення цього показника у Харківській ( $\approx 58 \%)$, Рівненській ( $>46 \%)$ і Вінницькій (35\%) областях. Зокрема, у Вінницькій області 30\% консервів і готових м'ясних продуктів, а у Харківській - 26,5\% м'ясних напівфабрикатів, реалізованих у торгівельній мережі, мають імпортне походження. Натомість Дніпропетровська, Запорізька, Кіровоградська і Полтавська області демонструють найвищий ступінь забезпеченості внутрішнього споживчого ринку м'ясом та продуктами з нього вітчизняного походження.

Висновки і перспективи подальших досліджень. В Україні домінує виробництво курятини. За останні 6 років наша країна перетворилась із нетто-імпортера цього виду м'яса в його неттоекспортера, увійшовши у ТОП-10 світових постачальників курятини і ТОП-3 - у країнах ЄС. Стрімкому розвитку названого сегмента сприяло нарощення потужностей та оновлення виробничої інфраструктури (у т.ч за рахунок дотацій із Держбюджету). Окрім того, виробництво курятини має ряд конкурентних переваг, порівняно з іншими видами м'яса, серед яких найкоротший цикл заготівлі м'ясної сировини і найнижча ціна. Як наслідок, упродовж останніх років стабільно зростає попит на цей вид м'яса як на внутрішньому, так і на світовому ринку, зокрема, у країнах, де інтенсивно збільшується кількість населення. Загалом позитивна динаміка виробництва м'яса птиці в Україні вказує на перспективи до подальшого розширення його експорту. За прогнозами, до 2030 року в ЄС можливе $24 \%$-е зростання попиту на імпортну продукцію в цьому сегменті, який могли б частково задовільнити вітчизняні виробники курятини. Підстави для оптимізму у цьому контексті дала наприкінці 2019 року ратифікація Європарламентом угоди з Україною, згідно з якою передбачено суттєве (на понад 50 тис. т) збільшення безмитних квот для експорту українського м'яса птиці до країн ЄС: до 68,4 тис. т у 2020 році і до 70 тис. т - у 2021-му. 3 огляду на досить високий рівень ввізного мита до ЄC для цієї продукції (від EUR19 до EUR130 за 100 кг чистої ваги), досягнуті домовленості сприятимуть посиленню позицій України як експортера цього виду продукції.

У 2021 році планується перегляд умов Поглибленої та всеохоплюючої зони вільної торгівлі між Україною та СC (Deep and Comprehensive Free Trade Area (DCFTA). Відтак, важливо ставити питання щодо диференціації квот на експорт різних видів продукції птахівництва, зокрема, курятину, індичатину та інші види м'яса. Це сприятиме виходу на європейські ринки нішевих видів продукції (м'яса качок, гусей, цесарок). Перевагою нішевих ринків птахівництва (і зовнішніх, і внутрішнього) $\epsilon$ те, що вони не монополізовані великими агропромисловими компаніями, що надає додаткові перспективи для вітчизняних товаровиробників як у площині експорту, так і в площині імпортозаміщення. Можливість нарощення експортного потенціалу і задоволення внутрішнього попиту на нішеві види м'ясної продукції стане додатковим стимулом для розвитку в Україні малого і середнього агробізнесу, оскільки в невеликих індивідуальних господарствах зосереджено вирощування близько 97\% поголів'я качок і 94\% - гусей. Своєю чергою, розширення сировинної бази сприятиме збільшенню обсягів промислового виробництва м'яса птиці та продуктів із нього, а саме: паштетів, м'ясних мусів та інших видів продукції поглибленої переробки. 3 огляду на новітні 
тенденції у зміні споживчих уподобань на користь дієтичних (нішевих) видів м'яса, цей напрямок розвитку птахівництва в Україні має великі перспективи, передусім у тих регіонах, де відсутні великі агропромислові компанії.

На противагу птахівництву, тренди у вітчизняному свинарстві здебільшого негативні. Так, станом на 1 січня 2020 року поголів'я основного стада свиней в Україні зменшилось на 4,9\%, порівняно з аналогічним періодом минулого року [5]. Водночас зменшення у 2019 році дефіциту свинини на внутрішньому ринку унаслідок активної реалізації свиней на забій, а також менш сприятливої для імпортних операцій цінової кон'юнктури (як на внутрішньому, так і на зовнішньому ринках) стали основними причинами скорочення імпорту цього виду м'яса в Україну.

Ще критичніша ситуація в Україні 3 виробництвом яловичини і телятини, що є прямим наслідком зменшення за останні 25 років поголів'я великої рогатої худоби (ВРХ) у понад 6 разів. Однією з основних причин скорочення поголів'я ВРХ заготівельного призначення $\mathrm{i}$, як наслідок, виробництва яловичини і телятини, була упродовж 1994-2016 років збиткова діяльність цього сегмента вітчизняного агропрому через високу собівартість виготовлення м'ясної продукції, високі терміни окупності капіталу, а також низькі закупівельні ціни на м’ясну сировину. Однак, продукція 3 яловичини $є$ одним із найбільш перспективних напрямків агропромислового експорту. Якщо всі умови і дозволи на експорт цього виду м'яса будуть погоджені 3 країнами Близького Сходу i Північної Африки, вітчизняний тваринницький сектор отримає новий імпульс для розвитку. Том пошук нових і розширення традиційних ринків збуту вбачається ключовим драйвером нарощення потенціалу вітчизняного виробництва яловичини в умовах низького внутрішнього попиту. У цьому напрямку будуть спрямовані подальші авторські дослідження за окресленою тематикою.

\section{Джерела та література}

1. Охріменко І.В. Наукові основи макроекономічного аналізу аграрного ринку. Агросвіт. 2015. №17. С. 3-7.

2. Ібатуллін М.I. Інституційне середовище продовольчого ринку: зарубіжний досвід і вітчизняне сьогодення. Вісник аграрної науки. 2015. №10. С. 64-68.

3. Мамчур Л.В. Формування організаційно-економічного механізму збалансованого розвитку ринку м'яса та м'ясопродуктів. Економіка АПК. 2017. №8. С. 38-47.

4. Бергер А.Д. Сучасні тенденції розвитку м’ясопереробної галузі України. Інтелект XXI. №1. 2017. С. 41-51.

5. Статистичний збірник “Тваринництво України”. Офіційний сайт Державної служби статистики України. 2019. URL: http://www.ukrstat.gov.ua/druk/publicat/kat_u/2019/zb/05/zb_tu2018.pdf

6. Виробництво промислової продукції за видами по регіонах. 2019. Офіційний сайт Державної служби статистики України. URL: http://www.ukrstat.gov.ua/operativ/operativ2003/pr/ovp/ovp_u/arh_ovp.html

7. Митна статистика. Офіційний сайт Державної фіскальної служби України. 2019. URL: http://sfs.gov.ua/ms/f11

8. Іщук С. О., Созанський Л. Й. Динаміка структурних змін у роздрібному товарообороті регіонів України. Соціально-економічні проблеми сучасного періоду України: зб. наук. пр. 2018. Випуск 6 (134). С. 8-14.

\section{References}

1. Okhrimenko, I. V. (2015). Naukovi osnovy makroekonomichnoho analizu ahrarnoho rynku [Scientific basis of macroeconomic analysis of the agricultural market]. A2pocвim - Agrosvit. No 17, P. 3-7. [in Ukraine].

2. Ibatullin, M. I. (2015). Instytutsiyne seredovyshche prodovol'choho rynku: zarubizhnyy dosvid i vitchyznyane s'ohodennya [Institutional environment of the food market: foreign experience and domestic present] Вісник аграрної науки - Bulletin of Agricultural Science. No 10, P. 64-68. [in Ukraine].

3. Mamchur, L. V. (2017). Formuvannya orhanizatsiyno-ekonomichnoho mekhanizmu zbalansovanoho rozvytku rynku m'yasa ta m'yasoproduktiv [Formation of organizational and economic mechanism for balanced development of the meat and meat products market]. Економіка АПК - The Economy of Agro-Industrial Complex. No 8, P. 38-47. [in Ukraine].

4. Berger, A.D. (2017). Suchasni tendentsiyi rozvytku m'yasopererobnoyi haluzi Ukrayiny [Current trends in the meat processing industry in Ukraine]. Інтелект XXI-Intellect XXI. No 1, P. 41-51. [in Ukraine].

5. Statystychnyy zbirnyk "Tvarynnytstvo Ukrayiny". Ofitsiynyy sayt Derzhavnoyi sluzhby statystyky Ukrayiny. 2019. URL: http://www.ukrstat.gov.ua/druk/publicat/kat_u/2019/zb/05/zb_tu2018.pdf [in Ukrainian]. 
6. Vyrobnytstvo promyslovoyi produktsiyi za vydamy po rehionakh. Ofitsiynyy sayt Derzhavnoyi sluzhby statystyky Ukrayiny. 2019. URL: http://www.ukrstat.gov.ua/operativ/operativ2003/pr/ovp/ovp_u/arh_ovp.html [in Ukrainian].

7. Mytna statystyka. Ofitsiynyy sayt Derzhavnoyi sluzhby statystyky Ukrayiny. 2019. URL: http://sfs.gov.ua/ms/f11 [in Ukrainian].

8. Ishchuk, S. O., \& Sozanskyy, L. Y. (2018). Dynamika strukturnykh zmin u rozdribnomu tovarooboroti rehioniv Ukrayiny [The dynamics of structural changes in rectangular warehouses of Ukraine regions]. In Sotsial'noekonomichni problemy suchasnoho periodu Ukrayiny [Socio-Economic Problems of the Modern Period of Ukraine]: Vol. 134 (6) (pp. 8-14). [in Ukrainian].

Стаття надійшла до редакції 20.02.2020 р. 